\title{
Drug Reaction With Eosinophilia and Systemic Symptom (DRESS) pada Tuberkulosis Payudara dalam Pengobatan
}

\author{
Rudi Erwin Kurniawan", Raveinal²
}

\begin{abstract}
Abstrak
Drug Reaction With Eosinophilia and Systemic Symptom (DRESS) atau sindroma DRESS merupakan suatu reaksi idiosinkratik yang terjadi setelah pemberian obat dalam dosis terapi yang ditandai dengan manifestasi klinis berupa adanya erupsi eritematosa, demam, kelainan hematologi terutama adanya eosinofilia dan adanya keterlibatan organ dalam seperti hepatitis, nefritis, limfadenopati, pneumonitis dan miokarditis. Sindroma DRESS sering disebabkan oleh obat seperti trimetropim, allopurinol, metronidazol, dapson dan abacavir. Penyaki ini juga dapat terjadi akibat reaksi silang obat, seperti obat anti konvulsan (carbamazepin, fenitoin, fenobarbital) dan obat anti inflamasi non steroid (piroksikam). Dilaporkan pasien wanita 34 tahun dengan keluhan utama kuning pada mata yang disertai bercak kemerahan pada wajah, badan, lengan dan tungkai. Manifestasi klinis muncul setelah pasien mengkonsumsi obat anti tuberkulosis selama 1,5 bulan. Pada pemeriksaan penunjang yang khas tampak eosinophilia dengan limfositik atipik dan keterlibatan organ dalam berupa hepatitis setelah menyingkirkan penyebab lain dari hepatitis. Setelah dilakukan penghentian obat anti tuberkulosis selama 2 mingga tampak perbaikan yang signifikan pada manifestasi kulit dan hematologi. Pasien kemudian dilakukan tes provokasi untuk menentukan obat yang menjadi penyebab terjadinya sindroma DRESS.
\end{abstract}

Kata kunci: DRESS, obat anti tuberkulosis, tuberkulosis payudara

\section{Abstract}

Drug Reaction With Eosinophilia and Systemic Symptom (DRESS) or DRESS syndrome is an idiosyncratic reaction that occurs after drug administration in therapeutic doses, which is characterized by a form of erythematous eruptions, fever, hematological abnormalities. The presence of eosinophilia and involvement of internal organs such as hepatitis, nephritis, lymphadenopathy, pneumonitis and myocarditis. DRESS syndrome is frequently caused by drugs such as trimethoprim, allopurinol, metronidazole, dapsone and abacavir. It also occurs due to cross-drug reactions, such as anti-convulsant drugs (carbamazepine, phenytoin, phenobarbital) and non-steroidal anti-inflammatory drugs (piroxicam). The purpose of this study is to provide information about DRESS syndrome due to anti-tuberculosis drug administration in breast tuberculosis. A report of a thirty-four-year-old female with her yellowish eyes accompanied by reddish spots on the face, body, arms and legs. Clinical manifestations appeared after the patient took antituberculosis drugs for 1,5 months. Investigation showed eosinophilia with atypical lymphocytes, and internal organ involvement in the form of hepatitis, in this patient other causes of hepatitis were excluded. After discontinuing antituberculosis drugs for two weeks, there were significant improvements in skin manifestations and hematological results. The patient was performed a provocation test to determine which drug caused the DRESS syndrome.

Keywords: anti tuberculosis drug, breast tuberculosis, DRESS

Affiliasi penulis: 1. RSUD Lubuk Basung 2. Bagian IImu Penyakit Dalam, Fakultas Kedokteran, Universitas Andalas, Padang, Indonesia Korespondensi: Rudi Erwin Kurniawan. Email: dr.rudierwin@gmail.com Telp: +628216114111

\section{PENDAHULUAN}

Drug Reaction with Eosinophilia and Systemic Symptom (DRESS) yang sering juga dikenal sebagai Drug Hypersensitivity Syndrome atau Hypersensitivity 
Syndrome Reaction (HSR) merupakan reaksi idiosinkratik yang terjadi pada pemberian obat dalam dosis terapi, yang ditandai adanya erupsi eritematous, demam, kelainan hematologi terutama adanya eosinofilia dan adanya keterlibatan organ dalam seperti: limfadenopati, hepatitis, pneumonitis, miokarditis, nefritis. ${ }^{1,2}$

Angka Insiden sindrom DRESS bervarasi, 1 diantara 1000 sampai 1 diantara 10.000 yang terpapar obat. Lebih sering mengenai dewasa dan kebanyakan kasus sporadik tanpa perbedaan jenis kelamin. Dalam praktik klinis, sindroma DRESS sering diabaikan karena manifestasi klinisnya beraneka ragam dan tampak seperti biasa saja. ${ }^{3}$

\section{Etiologi}

Sindroma DRESS sering disebabkan oleh obat seperti trimetropim, metronidazol, allopurinol, dapson dan abacavir, juga dapat terjadi akibat reaksi silang obat, seperti obat anti konvulsan (carbamazepin, fenitoin, fenobarbital) dan obat anti inflamasi non steroid ( seperti piroksikam). Pasien yang mengalami hipersensitivitas terhadap obat-obat tersebut, memiliki kemungkinan akan bereaksi terhadap obat lainnya sebesar $75 \%$. Penyebab lainnya adalah keterlibatan koinfeksi virus yaitu reaktivasi dari Human Herpes Virus-6 (HHV-6). ${ }^{4}$

Sindroma DRESS yang disebabkan oleh obat antituberkulosis sangat jarang terjadi. Satu studi kohort yang dilakukan di korea dari tahun 2006 - 2010 terhadap 1,253 pasien yang menggunakan OAT, 15 orang diantaranya mengalami DRESS syndrome $(1.2 \%) .^{5}$

\section{Manifestasi Klinis}

Pada sindroma DRESS dikenal trias klasik berupa demam, erupsi kulit, dan keterlibatan organ dalam. Demam dan malaise biasanya merupakan tanda yang pertama kali muncul. Demam dapat terjadi 2-3 hari sebelum atau bersamaan dengan erupsi kulit. Demam berkisar antara $38-39{ }^{\circ} \mathrm{C}$. Erupsi kulit muncul antara 1 sampai 8 minggu setelah terapapar dengan obat penyebab atau 2 bulan pertama dimana ruam kulit melibatkan setengah dari permukaan tubuh bahkan bias berkembang menjadi eritroderma. Erupsi kulit bervariasi, dapat menyerupai makulopapular pada hampir $95 \%$ kasus, vesikobulosa, papulopustular, eritroderma atau dermatitis eksfoliatif dan biasanya selalu disertai gejala gatal. Keterlibatan mukosa jarang ditemukan, tetapi seandainya ada biasanya hanya berupa stomatitis atau faringitis yang ringan. ${ }^{6}$

Kelainan sistemik atau keterlibatan organ dalam pada sindrom DRESS dapat asimptomatik atau dapat timbul setelah 1 sampai 2 minggu. Kelainan sistemik yang sering ditemukan adalah gangguan pada hati, berupa hepatitis (terjadi sekitar 75 - 94\%), nekrosis hati dan gagal hati. ${ }^{7}$

\section{Diagnosis}

Dalam menegakkan diagnosis sindroma DRESS terdapat tiga macam kriteria diagnosis yang dipakai untuk mendiagnosis sindrom DRESS yaitu kriteria Bocquet, RegiSCAR (The European Registry of Severe Cutaneous Adverse Reaction study group) dan J-SCAR (Japanese Research Committee on Severe Cutaneous Adverse Reaction group). ${ }^{8}$ 
Tabel 1. Perbedaan kriteria diagnosis sindrom DRESS ${ }^{8}$

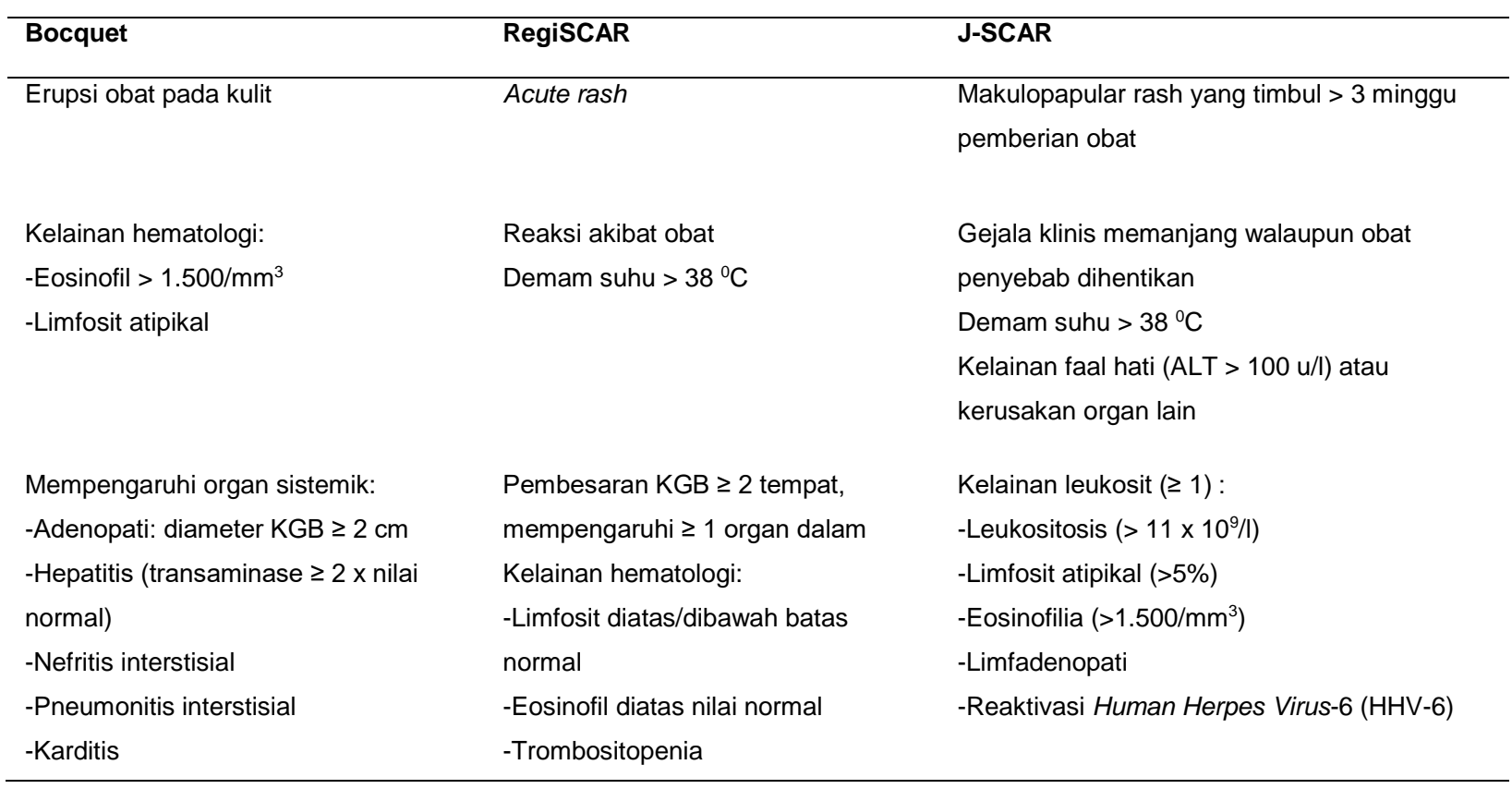

\section{KASUS}

Seorang wanita usia 34 tahun datang ke IGD RSUP Dr. M. Djamil Padang dengan keluhan utama mata tampak kuning sejak 5 hari sebelum masuk rumah sakit. Awalnya kuning hanya tampak membayang, namun lama kelamaan tampak makin jelas. Mual disertai muntah sejak 10 hari yang lalu, frekuensi muntah 3-5 kali sehari volume 1/4 gelas setiap kali muntah berisikan apa yang dimakan dan diminum. Demam sejak 8 hari yang lalu, demam tinggi, demam naik turun, tidak disertai menggigil dan tidak berkeringat banyak. Bercak merah disertai rasa gatal pada badan, wajah, kedua lengan, dan tungkai sejak 8 hari yang lalu, awalnya bercak yang timbul kecil-kecil, namun makin hari makin lebar.

Pasien sudah dikenal menderita TB payudara kanan sejak 1,5 bulan yang lalu. Pada enam bulan yang lalu, pasien mengeluhkan payudara terasa nyeri, kemudian muncul benjolan yang makin lama makin membesar. Kemudian benjolan pecah dan mengeluarkan darah bercampur nanah. Pasien berobat ke dokter di rumah sakit swasta di pekanbaru, pasien kemudian dilakukan operasi untuk mengangkat benjolan di payudara, kemudian dilakukan pemeriksaan jaringan. Dari hasil pemeriksaan histopatologi jaringan payudara, pasien dikatakan dokter menderita tuberkulosis payudara dan menjalani pengobatan tuberkulosis berupa obat paket yang diminum 4 tablet sehari.

Pasien bekerja sebagai ibu tangga. Pasien tinggal di rumah permanen bersama suami dan 2 orang anaknya. Ventilasi cukup, lingkungan rumah agak lembab, pencahayaan kurang. Rumah pasien berada paling sudut. Disekitar rumah pasien tidak ada orang yang batuk lama ataupun yang menderita tuberkulosis.

Pada saat datang ke IGD, didapatkan pasien sadar penuh, dengan tekanan darah 120/80 mmHG, frekuensi nafas $20 \mathrm{x} /$ menit, frekuensi nadi $82 \mathrm{x} /$ menit dan suhu tubuh $38,2^{\circ} \mathrm{C}$. pada pemeriksaan fisik didapatkan mata sklera ikterik. Status dermatologikus kulit didapatkan makula eritema, plak hiperpigmentasi dengan ukuran plakat dan batas tidak tegas pada badan, kedua lengan dan tungkai. 

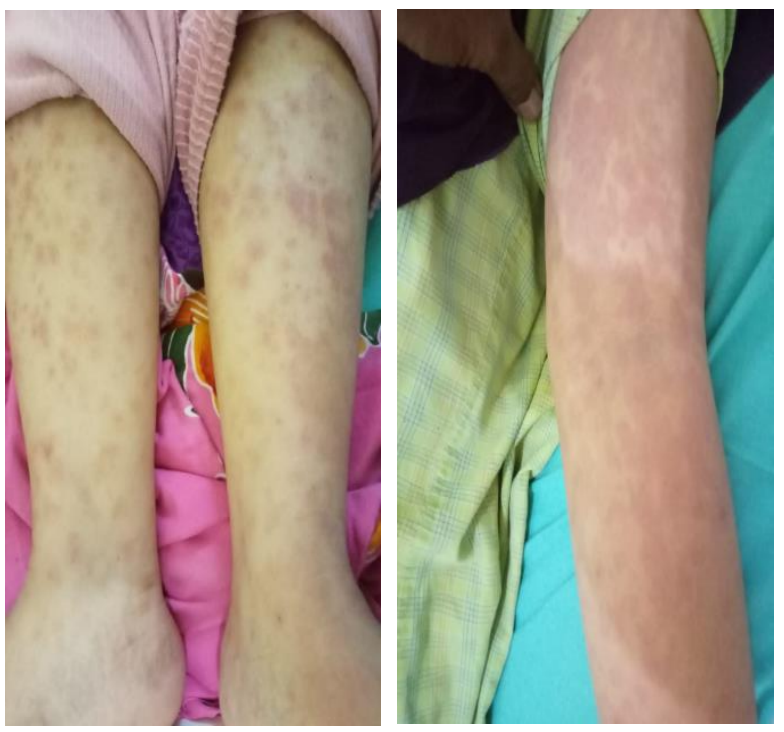

Gambar 1. Lesi kulit berupa makula eritema pada lengan dan tungkai

Pada Pemeriksaan penunjang didapatkan $\mathrm{Hb}$ : 10,1 $\mathrm{gr} / \mathrm{dl}$, leukosit: $30.950 / \mathrm{mm}^{3}$ dengan DC: 0/10/7/45/28/1 dan eosinofilia absolut: 3,095 × 109/L serta trombosit: $274.000 / \mathrm{mm}^{3}$. Pada gambaran darah tepi didapatkan eosinofilia dan limfosit atipik. Pada pemeriksaan kimia klinik didapatkan SGOT: 264 u/l, SGPT: $454 \mathrm{u} / \mathrm{l}$, bilirubin indirect: 0,9 mg/dl dan bilirubin direct 4,7 mg/dl. Pasien telah dilakukan pemeriksaan hepatitis marker berupa $\mathrm{HbSAg}$ : non reaktif, anti HCV : non reaktif dan IgM anti HAV: negatif. Pada pemeriksaan USG hati didapati kesan hapatomegali ec hepatitis akut.

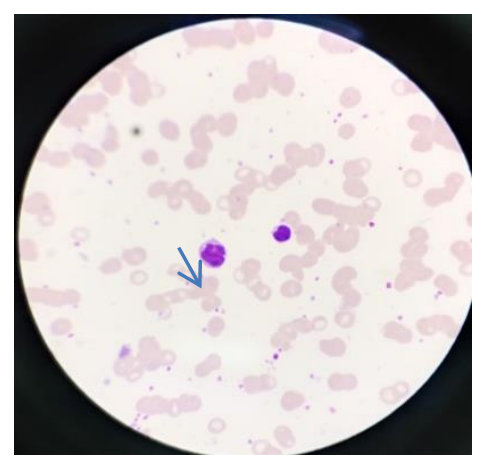

Gambar 2. Limfosit atipik

Setelah dilakukan penghentian obat anti tuberculosis selama 2 minggu maka tampak perubahan yang signifikan pada faal hepar. Dimana pada pemeriksaan laboratorium didapatkan SGOT: 26 u/l dan SGPT: $23 \mathrm{u} / \mathrm{l}$, sedangkan pada bilirubin indirect: $1,5 \mathrm{mg} / \mathrm{dl}$ dan bilirubin direct: $2,1 \mathrm{mg} / \mathrm{dl}$. Perubahan yang signifikan juga tampak pada ruam kulit, dimana makula eritema mulai menghilang.

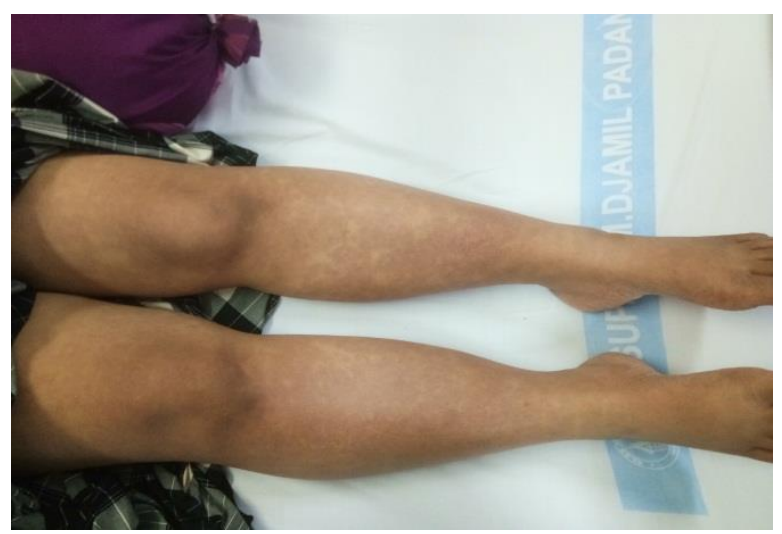

Gambar 3. Ruam kulit mulai menghilang setelah 2 minggu penghentian obat.

\section{PEMBAHASAN}

Seorang pasien wanita 34 tahun dengan diagnosis akhir: Drug Reaction with Eosinophilia and Systemic Symptom (DRESS) dan Tuberkulosis Payudara Dextra dalam pengobatan OAT kategori 1.

Drug Reaction with Eosinophilia and Systemic Symptoms (DRESS) pada pasien ini ditegakkan berdasarkan dari anamnesis adanya bercak-bercak merah disertai rasa gatal pada badan, wajah, kedua lengan, dan tungkai sejak 8 hari yang lalu, awalnya bercak yang timbul kecil-kecil, namun makin hari makin lebar. Mata tampak kuning semakin meningkat sejak 2 hari yang lalu. Awalnya kuning hanya tampak membayang, namun lama kelamaan tampak makin jelas. Mual disertai muntah sejak 10 hari yang lalu, frekuensi muntah 3-5 kali sehari volume 1/4- 1/2 gelas. Pasien telah dikenal menderita TB payudara kanan sejak 1,5 bulan yang lalu dan telah menjalani pengobatan OAT (obat paket) selama 1, 5 bulan.

Pemeriksaan fisik ditemukan adanya ruam makula eritema pada wajah, lengan, tungkai dan badan. Sklera ikterik dan disertai adanya hepatomegali. Dari pemeriksaan laboratorium dijumpai adanya penigkatan leukosit dan eosinofilia, limfosit atipik, peningkatan SGOT, SGPT dan bilirubin. Dari pemeriksaan USG abdomen ditemukan hepatomegali dan hepatitis akut. 
Berdasarkan data diatas pasien memenuhi kriteria diagnosis DRESS berdasarkan REGISCAR yaitu adanya ruam kulit, peningkatan leukosit, eosinofilia, limfosit atipikal dan kelainan organ dalam (hepatitis) yang muncul setelah 3 sampai 6 minggu mengkonsumsi obat. ${ }^{8}$

Eosinofilia terjadi ditemukan pada 60-70\% kasus dengan awitan setelah 1 sampai 2 minggu gejala muncul. Kelainan hati terjadi pada sekitar $70 \%$ pasien, ditandai oleh peningkatan enzim transaminase. Terjadinya hepatitis berat dengan kuning menjadi penanda prognosis buruk dan terkait dengan angka mortalitas yang meningkat. ${ }^{8}$

Penyebab DRESS pada pasien ini diduga adalah obat antituberkulosis yang digunakan pasien untuk tatalaksana tuberkulosis payudara yang diderita pasien 1,5 bulan yang lalu. DRESS akibat OAT sangat jarang terjadi. Satu studi kohort yang dilakukan di korea dari tahun 2006 - 2010 terhadap 1,253 pasien yang menggunakan OAT, 15 orang diantaranya mengalami DRESS syndrome (1.2\%) dengan rincian yang disebabkan etambutol 8 kasus, rifampisin 4 kasus, pirazinamid 3 kasus dan INH satu kasus. Suatu laporan kasus yang dilaporkan bahwa DRESS terjadi akibat OAT, obat yang menyebabkan DRESS pada keduanya adalah Rifampisin. Suatu studi yang dilakukan pada 38 orang pasien TB yang mengalami DRESS akibat OAT, rifampisin dan isoniazid diduga menjadi penyebab terbanyak DRESS. Sesuai dengan kasus diatas, pernah dilaporkan sebuah laporan kasus pasien DRESS akibat OAT, kemudian dilakukan uji tes kulit, obat yang menyebabkan reaksi adalah isoniazid. ${ }^{9}$

Berdasarkan data diatas dapat disimpulkan semua obat antituberkulosis berisiko menyebabkan DRESS. Pada pasien telah dilakukan pemberian OAT secara bertahap yang dimulai dengan pemberian INH dan etambutol dengan dosis terapi. Namun setelah beberapa jam mengkonsumsi obat tersebut pada pasien muncul keluhan kemerahan pada wajah, lengan dan tungkai yang disertai rasa gatal. Kemudian diputuskan untuk menghentikan kedua obat tersebut dan diberikan obat antihistamin. Pada pasien direncanakan untuk dilakukan tes alergi obat (Provocative drug challenge), karena mengingat pentingnya obat antituberkulosis pada pasien ini.
Namun untuk memulai tes ini pasien harus bebas antihistamin minimal selama lima hari. ${ }^{10}$

Provocative drug challenge tidak mengubah respon sistem imun. Prinsip dasar tes ini adalah pemberian obat secara hati-hati dan bertahap, sehingga reaksi ringan yang diketahui mungkin terjadi akan segera diketahui dan dapat dengan mudah diatasi. Setelah diketahui penyebab terjadinya sindroma DRESS pada pasien maka akan dilakukan pemilihan terapi OAT yang tepat untuk pasien. ${ }^{10}$

\section{SIMPULAN}

Pasien dengan sindroma DRESS dapat sembuh dengan penghentian obat yang diduga sebagai penyebabnya. Penyakit ini juga dapat mengancam nyawa sehingga deteksi dini dan tatalaksana yang tepat dapat menghindari keadaan yang fatal pada pasien.

\section{DAFTAR PUSTAKA}

1. James WD, Berger TG, Elston DM. Andrew's diseases of the skin: clinical dermatology. Edisi ke10. Philadelphia: WB Saunders Company; 2006

2. Roujeau JC, Mockenhaup M, Corona R. Drug reaction with eosinophilia and systemic symptoms (DRESS). Media Center-University of Freiburg, Germany. 2018;3:1-5

3. Tsu Cho Y, Wen Yang C, Yu Chu C. Drug Reaction with eosinophilia and systemic symptoms (DRESS): an interplay among drugs, viruses, and immune system. International Journal of Molecular Sciences. 2017;18(6):1-13.

4. Pichler WJ. Drug hypersensitivity reactions: classification and relationship to T-cell activation. Dalam: Pitchler WJ, editor (penyunting). Drug hypersensitivity. Basel: Karger;2007.hlm.168-89.

5. Jung HY, Park S, Shin B, Lee JH, Lee SJ, Lee $\mathrm{MK}$, et al. Prevalence and clinical features of drug reactions with eosinophilia and systemic symptoms syndrome caused by antituberculosis drugs: a retrospective cohort study. AAIR. 2018;10:4168.

6. Pinana E, Lei SH, Merino R. DRESS-syndrome on sulfasalazine and naproxen treatment for juvenile idiopathic arthritis and reactivation of human herpes virus 6in an 11 yearold Caucasian boy. J Clin Pharm Ther. 2015;35:365-70 
7. Kano Y, Ishida T, Hirahara K, Shiohara T. Visceral involvements and long-term sequelae in druginduced hypersensitivity syndrome. Med Clin North Am. 2010;94:743-59.

8. Kizilbash $Q$, Vasquez A, Seaworth B. Strategies for successful treatment of active tuberculosis in the setting of DRESS on RIPE. Open Forum Infectious Diseases. 2018;5:4.
9. Prasertcharoensuk A, Chongpison $Y$, Thantiworasit $\mathrm{P}$, Suthumcha N, Buranapraditkun S, Rerknimitr $\mathrm{P}$, et al. Hypersensitivity reactions to antituberculosis drugs confirmed by interferon gamma enzymelinked Immunospot assay. JACI. 2018;143; AB 26.

10. Jendoubi F,Jaber K, Rabhi F, Karray F, Youssef F, Dhaoui MR, et al. A positive patch test in an isoniazid-induced Dress syndrome. Our Dermatology online. 2017;8:110-1. 